\title{
The Double Mediating Effect of Start-Up Motive and Start-Up Spirit between Start-Up Opportunity Awareness and Expected Outcome af a Start-Up
}

\author{
Chang-Seek Lee, Mi-Hyang Choi
}

\begin{abstract}
The purpose of this study was to investigate the double mediating effect of start-up motive and start-up spirit between start-up opportunity awareness and expected outcome of a start-up. The subjects of this study were 251 employees living in Seoul, Daejeon, Chungnam, and Chungbuk in Korea. The collected data were analyzed using SPSS PC+ and PROCESS macro. Correlation analysis, reliability analysis, descriptive statistics, and mediation effect analysis were applied for data analysis. First, start-up opportunity awareness was positively correlated with start-up motive, start-up spirit, and the expected outcome of a start-up. Second, the start-up motive mediated the relationship between start-up opportunity awareness and the expected outcome of a start-up. Third, the start-up spirit mediated the relationship between start-up opportunity awareness and the expected outcome of a start-up. Fourth, start-up motive and start-up spirit both mediated the relationship between start-up opportunity awareness and the expected outcome of a start-up. Finally, based on the results of this study, the ways to overcome the low level of start-up spirit and the early closing rate of start-up were discussed.
\end{abstract}

Keywords : Start-up opportunity awareness, Start-up motive, Start-up spirit, Expected outcome of a start-up, Double mediating effect

\section{INTRODUCTION}

W ith the advent of the Fourth Industrial Revolution, manufacturing in the industrial field has been largely automated and digitized. All things are connected and intelligent throughout the network, and human life is expected to undergo drastic changes. Deep-tech fields such as Big Data, Artificial Intelligence, Augmented Reality, Virtual Reality, Robotics, and the Internet of Things are newly emerging as major technologies leading the fourth industrial revolution [1].

This fourth industrial revolution is expected to make our everyday life easier, but also that the automation of the machine will have negative consequences, such as loss of humanity and job loss [2]. In this way, when opportunities and crises coexist, new start-up activities through preemptive response and start-up spirit are attracting attention, because

Revised Manuscript Received on July 22, 2019.

Chang Seek Lee, Dept. of Health, Counseling and Welfare, Hanseo University, 31962, Republic of Korea. Email: lee1246@ hanmail.net

* Mi-Hyang Choi, Dept. of Lifelong Education, Hanseo University, Seosan, Korea, Email: vmfms0830@naver.com they can lead to new growth engines and job creation [3-6].

The entrepreneurial environment is also undergoing major changes. In the past, jobs have increased in proportion to state-led economic growth. However, as the per-capita income reaches US $\$ 30,000$, there is no longer an increase in the employment rate [7]. This lack of jobs and the stagnation of the employment rate have led to youth unemployment and early retirement problems and have had a negative effect on social anxiety, national growth potential, and poverty problems [8]. Therefore, the social interest in start-up activities has increased as an alternative means towards start-up opportunity awareness, and the start-up atmosphere has also gradually grown.

The government provided measures to support entrepreneurship in order to discover new growth engines and create jobs [9]. The government's various start-up policies and budgets are increasing every year, and they are actively promoting young start-ups to create jobs to mitigate low growth, low employment, and early retirees and to secure growth engines [10]. Related support policies and projects are being expanded to solve the unemployment of youth and middle-aged men. The government's main start-up support policy is to promote a start-up spirit and promote start-up activities. This support policy is expected to lead to motivate achievement and wealth creation for the individual as well as to drive economic growth and new employment nationwide [11].

In this way, various support policies are being set up at the government level, and even though the business environment is rising in social terms, limitations on the start-up outcomes and the related problems are also revealed. As for the numerical achievements of start-ups, as of the end of 2015, there were 2,001,674 surviving enterprises in the seven years since the start of business, which is steadily increasing compared to 1,893,716 in 2013 and 1,985,396 in 2014 [12]. Among them, private companies are expected to account for $93.3 \%$ in $2013,91.8 \%$ in 2014 , and $89.2 \%$ in 2015 , but this figure is gradually decreasing, reflecting the social climate in which the pace of change is rapid and uncertainty is high, which is always relevant to the high unemployment rate $[13,14]$, On the other hand, the desire for self-realization is highly related to individual motivation for achievement to focus on various opportunities and desires [15]. 
However, looking at the survival rate of companies in order to assess the quality of start-ups is by no means optimistic. As of the end of 2015 , there were 520,297 (26.0\%) companies that had survived for one year, $402,369(20.1 \%)$ for two years, $308,413(15.4 \%)$ for three years, $241,327(12.1 \%)$ for four years, $206,614(10.3 \%)$ for five years, $174,111(8.7 \%)$ for six years, and $148,543(7.4 \%)$ for seven years. These figures show that $26.0 \%$ of all start-ups were closed within one year[12]. Only $38.5 \%$ of surviving companies have survived for more than three years, which is less than half. This is similar to $39.2 \%$ in 2013 and $38.6 \%$ in 2014 , confirming that the closure rate problem has already become chronic. Therefore, the resulting social costs cannot be overlooked, and a strategic approach to start-ups is needed.

Although the state and local governments have provided support measures, start-up outcomes still have problems in many aspects, such as start-up rate, survival rate, and employment creation. In this study, we examined the reasons for these problems by looking at the psychological foundation related to start-ups. In order for successful start-ups to take place, systematic and sustainable capabilities of entrepreneurs are required [16], because entrepreneurs try to acquire relevant knowledge, establish networks, and develop technology by working with other entrepreneurs because of the lack of various resources at the time of start-up. These activities are based on the competencies of entrepreneurs [17], which can be divided into two types: competencies borne by entrepreneurs and competencies acquired through learning activities of their own. The acquired competencies are to strengthen start-up motive and start-up spirit through systematic entrepreneurial education systems and programs [18].

Therefore, in order to achieve successful start-up outcomes, entrepreneurial capacity is a very important issue. It is possible to improve the entrepreneurial psychological aspects, such as start-up spirit and motive, through a systematic and positive entrepreneurial education system. Recent studies have reported that individual emotional factors affect entrepreneurs' behavior. In this context, entrepreneurship-related psychology is expected to have a significant effect on start-up outcome, which is the final variable [19]. Therefore, in order to increase the success rate of start-ups, it is necessary to understand the various psychological characteristics of start-ups.

However, existing studies mainly focus on direct effects of start-up related variables, but there is no research that has identified the structural relationship of start-up motive and spirit to start-up opportunity awareness and the expected outcome of a start-up.

Therefore, in this study, we try to suggest ways to overcome the low start-up rate and the early closing rate of start-ups by grasping the mediating roles of start-up-related psychological variables, such as start-up motive and start-up spirit, in the relationship between start-up opportunity awareness and the expected outcome of a start-up.

In order to achieve this goal, the research questions are: First, what is the correlation between start-up opportunity awareness, start-up motive, start-up spirit, and the expected outcome of a start-up? Second, do both start-up motive and start-up spirit mediate start-up opportunity awareness and the expected outcome of a start-up?

The results of this study are meaningful in providing basic data related to the theoretical basis and the national start-up policy in order to secure the competitive advantage of pre -founders and the successful foundation of start-ups.

\section{RESEARCH METHOD}

\section{A. Research Model}

The research model seeks to understand whether start-up motive and start-up spirit mediate in the relationship between start-up opportunity awareness and the expected outcome of a start-up as shown in Figure 1.

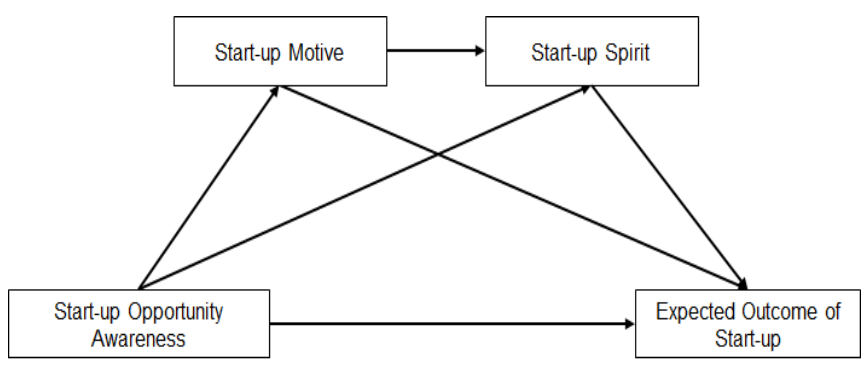

Figure 1: Research model

\section{B. Research Subject}

The subjects of this study were selected from twenty workplaces in four metropolitan cities and provinces: Seoul, Daejeon, Chungnam, and Chungbuk. First of all, the questionnaire was completed after conducting a preliminary survey on 30 employees and reviewing the items. This survey was conducted by distributing and collecting the questionnaires directly, after the purpose of the research was explained to the employees of the selected workplaces.

\section{Research Tools}

- Start-up opportunity awareness

Start-up opportunity awareness was measured using the scales used by Kim [20], Choi [21], and Oh [22]. The scale consists of four items, but was measured with three items after removing one item that lowered the reliability. Each item used a 5-point Likert scale ranging from " $1=$ not at all" to "5 = strongly agree". The higher the score, the higher the opportunity recognition for a start-up. In this study, the Cronbach alpha for start-up opportunity awareness was 0.830 .

- The expected outcome of a start-up

The expected outcome of the start-up was measured using the construct of Yoon [23] based on the scale of Kang [24] and Han [25], The scale consists of five items including self-start-up motive, status, expected outcome in profit, and expected outcome of local development. Each item used a 5-point Likert scale ranging from " $1=$ not at all" to "5 = strongly agree". The higher the score, the higher the expected outcome of a start-up. In this study, the Cronbach alpha for expected outcome of the start-up was 0.796 .

- Start-up motive 
Start-up motive was measured using the constructs of Yoon [23], Kang [24], Han [25], and Ahn [26]. The scale consists of seven items including achievement desire, job anxiety, livelihood of a start-up, job satisfaction, succession of family business, start-up idea, and achievement. Each item used a 5-point Likert scale ranging from " $1=$ not at all" to "5 = strongly agree". The higher the score, the higher the motivation for a start-up. In this study, the Cronbach alpha for expected outcome of the start-up motive was 0.824 .

- Start-up spirit

Start-up spirit was measured using a modified and reconstructed scale of Kim [27] based on the scale developed by Kim[28], The scale consisted of 12 questions, four items of innovation, four items of progressiveness, and four items of risk sensitivity. Innovation included efforts to develop new products, to improve management performance through innovation, to improve corporate management through innovation, and to improve creative marketing development. Progressiveness included four items: progressive attitude toward new product development, progressive action through new opportunities, niche market penetration, and market creation efforts. Risk sensitivity included four items: risk-taking attitude, preference for challenging work, establishment of a growth strategy within uncertainty, and high-risk and high-profit business. Each item used a 5-point Likert scale ranging from " $1=$ not at all" to " $5=$ strongly agree". The higher the score, the higher the entrepreneurial spirit. In this study, the Cronbach alpha for expected outcome of the start-up motive was 0.904 .

\section{Data Analysis}

We analyzed the reliability, descriptive statistics, and correlations between variables by using SPSS Win 23.0. The double mediating effect analysis of the research model (Figure 1) was done by using PROCESS macro 3.2.

\section{RESULTS AND DISCUSSION}

\section{A. Correlation between the main variables and descriptive statistics}

Correlation analysis was performed to find the correlations between the main variables. The results are shown in Table 1. Start-up opportunity awareness was positively correlated with start-up motive, start-up spirit, and the expected outcome of a start-up. There was also a significant positive correlation between the other major variables. Among them, the correlation coefficient between start-up opportunity awareness and start-up spirit was the highest $(r=.457, \mathrm{p}<$ $.01)$, followed by the correlation coefficient between start-up opportunity awareness and the expected outcome of a start-up $(\mathrm{r}=.403, \mathrm{p}<.01)$. These results suggest that start-up opportunity awareness as well as start-up motive and start-up spirit can promote the expected outcome of a start-up. In particular, it is reasonable to strengthen start-up spirit in order to improve the expected outcome of a start-up when resources and time are limited. It is then necessary to sequentially promote start-up opportunity awareness and start-up motives.

Descriptive statistics showed that start-up motive was 2.88, which was lower than median (3 points), but start-up opportunity awareness, start-up spirit, and the expected outcome of a start-up were higher than 3 points. In other words, the start-up motive is less than the mid-point, so the first thing to improve is the start-up motive by means of start-up education. In addition, other variables, such as start-up opportunity awareness and start-up spirit, did not have high scores. Therefore, it is necessary to increase start-up opportunity awareness, start-up motive, and start-up spirit by means of start-up education, thereby expanding start-up opportunities and increasing start-up success.

Table 1: Correlation between the main variables and descriptive statistics

\begin{tabular}{|c|c|c|c|c|c|c|}
\hline & 1 & 2 & 3 & 4 & M & SD \\
\hline 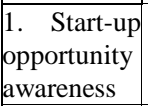 & 1 & & & & 3.0413 & 0.69136 \\
\hline $\begin{array}{l}\text { 2. Start-up } \\
\text { motive }\end{array}$ & $0.368^{* * *}$ & 1 & & & 2.8827 & 0.61379 \\
\hline $\begin{array}{l}\text { 3. Start-up } \\
\text { spirit }\end{array}$ & $0.457^{* *}$ & $0.295^{\text {** }}$ & 1 & & 3.2748 & 0.54845 \\
\hline $\begin{array}{l}\text { 4. Expected } \\
\text { outcome of } \\
\text { a start-up }\end{array}$ & $0.403^{\text {*** }}$ & $0.340^{* * *}$ & $0.431^{* *}$ & 1 & 3.2494 & 0.61066 \\
\hline
\end{tabular}

\section{B. The double mediating effect of start-up motive and spirit}

In order to verify the double mediating effect of start-up motive and start-up spirit on the relationship between start-up opportunity awareness and the expected outcome of a start-up, we used the SPSS PROCESS macro model 6 proposed by Hayes. Figure 2 and Table 2 show that start-up opportunity awareness had a significant effect on start-up motive $(0.3271, \mathrm{p}<0.001)$, and start-up motive had a significant effect on the expected outcome of a start-up $(0.1786, \mathrm{p}<0.01)$. Therefore, the start-up motive mediated the relationship between start-up opportunity awareness and the expected outcome of a start-up.

In addition, start-up opportunity awareness had a significant effect on start-up spirit $(0.3200, \mathrm{p}<0.001)$ and start-up spirit had a significant effect on the expected outcome of a start-up $(0.3174, \mathrm{p}<0.01)$. This means that start-up spirit has a simple mediating effect on the relationship between start-up opportunity awareness and the expected outcome of a start-up.

In other words, these results indicate that start-up opportunity awareness is the cause of start-up motive and start-up spirit. Furthermore, start-up motives and start-up spirits are the causal variables that influence the expected outcome of a start-up, and are also mediators in relation to start-up opportunity awareness. Considering this, it is necessary to improve the expected outcome of a start-up and finally to increase the success rate of start-ups.

Start-up motive had a significant effect on start-up spirit $(0.1310, \mathrm{p}<0.05)$. This indicated that both start-up motive and start-up spirit mediate the relationships between start-up opportunity awareness and the expected outcome of a start-up. The double-mediated effect of the start-up motive and start-up spirit suggests that in order to increase the expected outcome of the start-up, a method of increasing 
simultaneously and indirectly the start-up motive and the start-up spirit is effective.

On the other hand, the total effect of start-up opportunity awareness on the expected outcome of a start-up was 0.3571 ( $p<0.001)$, but the direct effect of the start-up opportunity awareness on the expected outcome of a start-up was reduced to 0.1835 ( $\mathrm{p}<0.01)$, when start-up motive and start-up spirit were introduced to the research model. This result implies that start-up motive and start-up spirit play a mediating role. As a result, two simple mediating effects and one double-mediating effect were observed.

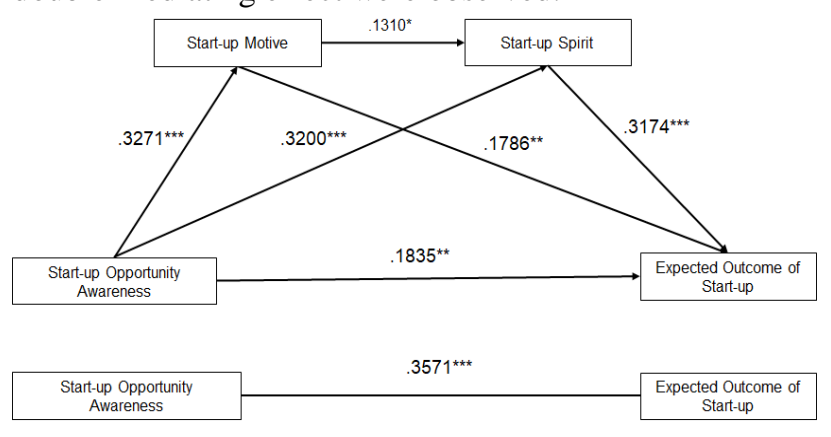

$* p<0.05, * * p<0.01, * * * p<0.001$

Figure 2: Results of double mediating effect analysis

Table 2: Results of double mediating effect analysis

\begin{tabular}{|c|c|c|c|c|c|c|c|}
\hline Variables & $\beta$ & SE & $\mathrm{t}$ value & $p$ & LLCI & ULCI \\
\hline \multicolumn{7}{|c|}{ Mediating variable model (DV: Start-up motive) } \\
\hline Constant & 1.8881 & 0.1638 & 11.5248 & 0.0000 & 1.5654 & 2.2107 \\
\hline $\begin{array}{c}\text { Start-up } \\
\text { opportunity } \\
\text { awareness }\end{array}$ & 0.3271 & 0.0525 & 6.2260 & 0.0000 & 0.2236 & 0.4305 \\
\hline \multicolumn{7}{|c|}{ Mediating variable model (DV: Start-up spirit) } \\
\hline Constant & 1.9259 & 0.1714 & 11.2338 & 0.0000 & 1.5882 & 2.2635 \\
\hline $\begin{array}{c}\text { Start-up } \\
\text { opportunity } \\
\text { awareness }\end{array}$ & 0.1310 & 0.0536 & 2.4432 & 0.0153 & 0.0254 & 0.2366 \\
\hline $\begin{array}{c}\text { Start-up } \\
\text { motive }\end{array}$ & 0.3200 & 0.0477 & 6.7093 & 0.0000 & 0.2261 & 0.4140 \\
\hline \begin{tabular}{c} 
Dependent variable model (DV: Expected outcome of start-up) \\
\hline Constant
\end{tabular} 1.1359 & 0.2294 & 4.9525 & 0.0000 & 0.6841 & 1.5876 \\
\hline $\begin{array}{c}\text { Start-up } \\
\text { opportunity } \\
\text { awareness }\end{array}$ & 0.1786 & 0.591 & 3.0231 & 0.0028 & 0.0622 & 0.2949 \\
\hline $\begin{array}{c}\text { Start-up } \\
\text { motive }\end{array}$ & 0.3174 & 0.0693 & 4.5836 & 0.0000 & 0.1810 & 0.4538 \\
\hline Start-up spirit & 0.1835 & 0.0565 & 3.2498 & 0.0013 & 0.0723 & 0.2947 \\
\hline
\end{tabular}

Table 3 shows the indirect effects of start-up motive and start-up spirit using a bootstrap. The indirect effect of start-up motive on the relationship between start-up opportunity awareness and the expected outcome of a start-up was confirmed, because there was no zero in the upper and lower limits of the bootstrap. On the other hand, the indirect effect of start-up spirit on the relationship between start-up opportunity awareness and the expected outcome of a start-up was verified because of the absence of zero in the upper and lower limits of the bootstrap. Finally, the indirect effect of the dual mediation by start-up motive and spirit on the relationship between start-up opportunity awareness and the expected outcome of a start-up was confirmed by the absence of zero in the upper and lower limits of the bootstrap.

Indirect effect verification can make it possible to compare the indirect effect of simple mediation of each start-up motive and the start-up spirit, and the double mediation of the start-up motive and the start-up spirit. As shown in Table 3, the indirect effect of double mediation was higher than the indirect effect of simple mediation (0.1016). Also, the indirect effect of simple mediation (0.0584) of the start-up motive was higher than that of the start-up spirit (0.0136). These results give important implications for the prioritization of contents selection in the development of start-up education and programs.

Table 3: Verification of indirect effects of start-up motive and start-up spirit

\begin{tabular}{|c|c|c|c|c|}
\hline \multicolumn{1}{|c|}{ Path } & Effect & Boot SE & BootLLCI $^{*}$ & BootULCI $^{* *}$ \\
\hline Total & 0.1736 & 0.0416 & 0.0964 & 0.2600 \\
\hline $\begin{array}{l}\text { Ind1: Start-up opportunity } \\
\text { awareness } \rightarrow \text { start-up } \\
\text { motive } \rightarrow \text { expected outcome } \\
\text { of start-up }\end{array}$ & 0.0584 & 0.0237 & 0.0197 & 0.1139 \\
$\begin{array}{l}\text { Ind2: Start-up opportunity } \\
\text { awareness } \rightarrow \text { start-up spirit }\end{array}$ & 0.0136 & 0.0082 & 0.0025 & 0.0376 \\
$\begin{array}{l}\text { start-up expected outcome of } \\
\begin{array}{l}\text { Ind3: Start-up opportunity } \\
\text { awareness } \rightarrow \text { start-up } \\
\text { motive } \rightarrow \text { start-up spirit } \rightarrow \\
\text { expected outcome of } \\
\text { start-up }\end{array}\end{array}$ & 0.1016 & 0.0302 & 0.0491 & 0.1698 \\
\hline
\end{tabular}

* LLCI $=$ boot Lower bound on $95 \%$ confidence interval of the indirect effect

** ULCI $=$ boot Upper bound on $95 \%$ confidence interval of the indirect effect

\section{CONCLUSION}

The purpose of this study is to suggest a way to overcome the low rate of start-ups and the early closing rate of start-ups by analyzing the psychological variables related to start-up, i.e., start-up motive and start-up spirit, in the relationship between start-up opportunity awareness and the expected outcome of a start-up.

The conclusions of the study are as follows.

First, start-up opportunity awareness was positively correlated with start-up motive, start-up spirit, and the expected outcome of a start-up. There was also a significant positive correlation between the other major variables.

Second, the start-up motive mediated the relationship between start-up opportunity awareness and the expected outcome of a start-up. The start-up spirit also mediated the relationship between start-up opportunity awareness and the expected outcome of a start-up. Start-up motive and start-up spirit showed the double serial mediation effect in the relationship between start-up opportunity awareness and the expected outcome of a start-up.

Based on the results of the study, suggestions for future research are as follows. First, we focused on the relationship between variables related to start-ups. In future research, it is necessary to identify the differences between individual characteristics and the causes of difference, and thus to increase the effect of a start-up. Second, the population for the study was the total number of workers in Korea. In future research, it is necessary to grasp the start-up outcome according to job type, to propose the jobs related to start-ups with high profit, and to increase the success rate of the start-up business. 


\section{ACKNOWLEDGMENT}

This study was undertaken with the support of a research grant in 2019 from Hanseo University.

\section{REFERENCES}

1. K. Schwab. The Fourth Industrial Revolution. United States: Crown Business, 2016.

2. J. G. Na, J. D. Kim. "The critical review on the 4th industrial revolution: In the perspective of the institutional thought of lewis mumford" Journal of social science, 56(2), 389-419, 2017. DOI :10.22418/JSS.2017.12.56.2.389

3. D. K. Won, S. P. Lee. "Artificial intelligence and implications of the fourth industrial revolution" Industrial Engineering Magazine, 23(2), 13-22, 2016

4. P. F. Drucker. Innovation and entrepreneurship: practice and principles. New York: Harper and Row, 1985

5. J. B. Barne. "Firm resources and sustained competitive advantage" Journal of Management, 17(1), 99-120, 1991.

6. S. M. C. Dollinge. "Identity styles and the five-factor model of personality" Journal of Research in Personality, 29(4), 475-479, 1995.

7. Y. J. Cho. "A comparative study on the influence of personal characteristics and social environment on the intention of entrepreneurship in Korea, China, Japan, Hong Kong university students knee" Ph.D Thesis, Hoseo University, 2016. http://www.riss.kr.libmeta.knou.ac.kr:8010/link?id=T14298778

8. J. S. Ryu, M. J. Son, J. Park, D. U. Eom, C. Y. Lee. "University education innovation plan for expanding youth employment" Issue Paper. Samsung Economic Research Institute, 132(3), 1-86, 2010. http://www.seri.org/db/dbReptV.html?menu=db01\&pubkey=db20100 827001

9. J. K. Hong. "The effects of individual characteristics, social capital, foundation policy environment of founder on entrepreneurial intention: Focusing on start-up spirit and value orientation" Ph.D Thesis, Seoul Venture University, http://www.riss.kr.libmeta.knou.ac.kr:8010/link?id=T14291298

10. N. G. Park, M. S. Kim, J. W. Ko. "The effect of the government's entrepreneurial support policy on start-up spirit and entrepreneurial intention" Asia-Pacific Journal of Business Venturing and Entrepreneurship, 10(6), 89-98, 2015.

11. S. H. Oh, K. S. Ha. "Effects on Entrepreneurial Intention by Start-up Environment and Self-efficacy Mediated by Fear of Business Failure" Journal of Digital Convergence, 11(8), 143-157, 2013. https://www.earticle.net/Article/A202595

12. Small Venture Business Department [Internet]. Seoul: Survey on the status of start-up companies;[cited 2018 April 13] https://www.mss.go.kr

13. Y. G. Suh, S. K. Kim. "Policy Study on Korean Retail Micro Business" Journal of channel and retailing, 17(5), 39-57, 2012. http://www.riss.kr.libmeta.knou.ac.kr:8010/link?id=A99682935

14. J. Y. Kim, Y. L. Lee. "An analysis of the impact of entrepreneurial activities in Pusan on regional economic growth and reduction of unemployment rate" Asia-Pacific Journal of Business Venturing and Entrepreneurship, 11(6), 111-122, 2016 http://www.riss.kr.libmeta.knou.ac.kr:8010/link?id=A103200356

15. D. Y. Chung, Y. H. Chae. "The effect of employability on the entrepreneurial intention: focus on double mediation role of self-leadership and self-efficacy" Korean Journal of Business Administration, 29(3), 467-488, 2016.

16. J. H. Bang, S. M. Park, J. K. Shin. "Exploratory study on perceived critical sucess factors for young entrepreneurs in the early startup stage" Asia-Pacific Journal of Business Venturing and Entrepreneurship, 9(5), 247-254,

2014 http://www riss.kr.libmeta.knou.ac.kr:8010/link?id=A101195008

17. S. T. Kim. "The effect of the psychological characteristics on the entrepreneurial intention among chinese college students: on the moderating effect of social supports" Master's Thesis, Soongsil University, http://www.riss.kr.libmeta.knou.ac.kr:8010/link?id=T13369117

18. H. S. Howard, F. M. Daniel, A. T. Jeffry. "Venture capital in transition: A Monte-Carlo simulation of changes in investment patterns" Journal of Business Venturing, 2(2), 103-121, 1987.

19. S. L. Han, M. S. Lee. "Effects of salesperson's compensation orientation on emotional labor, emotional exhaustion and adaptive selling behavior" Journal of Korean Marketing Association, 31(2), 73-92, 2016. DOI $: 10.15830 / \mathrm{kmr} .2016 .31 .2 .73$
20. H. M. Kim. "Study of influencing effects of one-person entrepreneur's start-up spirit to the recognition of business establishment opportunity and business establishment will: study about regulating effects of sns uti" Master's Thesis, Jung-Ang University, 2013. http://www.riss.kr.libmeta.knou.ac.kr:8010/link?id=T13257269

21. M. C. Choi. "A Study about the effects of youth business support on entrepreneurial opportunities perception and entrepreneurial intention for university students majoring in food service" Master's Thesis, Daegu Catholic University, 2014 http://www.riss.kr.libmeta.knou.ac.kr:8010/link?id=T13534549

22. S. H. Oh. "A comparative study of the influence of start-up environments on young adults and seniors' entrepreneurial intention: Focusing the mediating role of start-up spirit" Ph.D Thesis, Hoseo University, 2013 http://www.riss.kr.libmeta.knou.ac.kr:8010/link?id=T13424765

23. I. M. Yoon. "Study on the effects of youth entrepreneurs' entrepreneurial motivation on entrepreneurial performance: focusing on undergraduates" Master's Thesis, Jung-ang University, 2017. http://www.riss.kr.libmeta.knou.ac.kr:8010/link?id=T14428515

24. S. B. Kang. "Report on corporation performance influenced by entrepreneur's motive, entrepreneurship, and advanced preparation" Master's Thesis, Jung-ang University, 2012 http://www.riss.kr.libmeta.knou.ac.kr:8010/link?id=T12684182

25. K. S. Han. "An empirical study on the nascent start-up motivations and growth intentions" Ph.D Thesis, Seongsil University, 2012 http://www.riss.kr.libmeta.knou.ac.kr:8010/link?id=T12858817

26. S. G. Ahn. "Effects of entrepreneurship education and institutional support on entrepreneurial self-efficacy and entrepreneurial intention" Ph.D Thesis, Jung-ang University, 2016 http://www.riss.kr.libmeta.knou.ac.kr:8010/link?id=T14021580

27. S. S. Kim. "A study on effect of social support on baby boomer's entrepreneurial opportunity competence: Focusing on mediating effect of entrepreneurial self-efficacy. asia-pacific journal of business venturing and start-up spirit" Ph.D Thesis, Hoseo University, 2018. http://www.riss.kr.libmeta.knou.ac.kr:8010/link?id=T14687511

28. W. J. Kim. "Effects of start-up spirit and strategic orientation on the firm performance: Moderated mediation effect of digital literacy and learning orientation" Ph.D Thesis, Jung-ang University, 2016 http://www.riss.kr.libmeta.knou.ac.kr:8010/link?id=T14170677

\section{AUTHORS PROFILE}

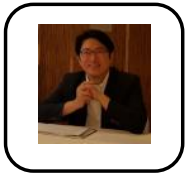

Chang Seek Lee received Bachelor's and Master's degree in lifelong education from Seoul National University in Korea and Ph.D. in lifelong education from University of the Philippines in the Philippines in 1991. $\mathrm{He}$ is chairman of health, counseling and welfare department of Hanseo University, South Korea and Head of Multicultural Education and Welfare Institute of Hanseo University. His primary research interests are program development, lifelong education and multicultural education.

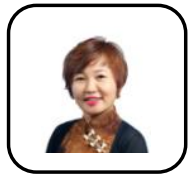

Mi-Hyang Choi is taking a Ph.D. programs in lifelong education department of Hanseo University. Her primary research interests are lifelong education and counseling psychology. 